УДК 069; ББК 79.1; DOI https://doi.org/10.21638/spbu19.2018.201

V. Ananiev, I. Katsaridou

\title{
THIS OBSCURE OBJECT OF DESIRE: OBJECT, PHOTOGRAPHY, MUSEUM AND DAMAGED CHURCHES
}

\section{THE OBJECT/THING IN HISTORY: AN OVERVIEW}

An overview of studies dedicated to the problem designated in the title of this issue "Thing in history" - facilitates the outlining, in general terms, of two stages to this approach: in the first stage, things are viewed as sources of historical evidence, while at the next stage they are interpreted as historical actors. The development of both paradigms is related to the more complex process of the evolution of scholarly knowledge as a cultural element, which comprises the formation of independent areas of study (auxiliary historical sciences, museum studies, cultural studies, material culture history, etc.) and their reconfiguration and crossing within the emerging interdisciplinary environment. The concept of material objects being pieces of historical evidence, frequently interpreted not as mere equivalents of documentary evidence but exceeding them in terms of reliability and accuracy (e.g. see the ideas of J. Spohn), dates back to the $17^{\text {th }}$ century, although their occasional interpretation in this sense can be found as early as in the works of the humanists. On the one hand, this was a result of the enhancement of the role of empirical science as a basis for the modern strategy of creating knowledge. On the other hand, the related, yet lesser spread of Cartesianism as a fundamental epistemological model based on an explicit subject/object dichotomy, likely contributed to it. Cartesian ideas legitimized the interpretation of objects as passive recipients of the subject>s active will (including the cognitive), thus converting them into an ideal source for sharing or extracting knowledge. For almost two centuries that followed, material objects, along with historical evidence, continued to remain marginal in the dominating humanist knowledge discourse, in contrast to documentary sources.

No significant changes in this approach evolved until the turn of $20^{\text {th }}$ century, when, as S. Marchand observes, it was the focus on material ("the rhetoric of artefacts") that allowed historians to review the customary categories of "the civilized" and "the barbarian" and to overcome the boundaries of the Romantic Nationalism that had evolved a century 
earlier" ${ }^{1}$ His contemporary K. Lamprecht, referred to by P. Miller as "the father of the $20^{\text {th }}$ century "materiality turn"", also regarded material objects as core material for composing cultural history in the broadest sense. The latest studies have demonstrated the relevance of this phenomenon to Russian historical studies through its relation to the late imperial epistemological revolution, which focused on the heterogeneity of cultural areas, in contrast to being constrained to homogeneous mono-national habitats.

The transition to the paradigm of interpreting things as historical process actors is associated with the latter half of the $20^{\text {th }}$ century and is largely defined by new approaches in interpreting the notion of culture, which is core to this agenda, and outlining the most challenging area in cultural studies. In this article, which by no means a complete and detailed historiographical review, we consider several publications relevant to the subject matter of our focus. In 1979 the British cultural studies specialist and social anthropologist M. Thompson published his original "rubbish theory", relating the existence of the society per se to the models followed by material objects within the context of their social existence ${ }^{3}$. Thompson pointed out that the Western model of perceiving the world, based on Cartesian philosophy, tends to classify objects surrounding man into two opposite, binary categories: transient and durable. The former decreases in value over time and has a finite life span. The latter, in contrast, increases in value over time and (ideally) has an infinite life span. The way we act towards an object relates directly to its category membership ${ }^{4}$. To this effect, an object's membership in one category and its potential transition to the other, rather than being related to inherent properties of the object, constitutes social acts that make possible the existence of the object. It is for this reason that Thompson introduced one of the core ideas of his theory, "rubbish," conceptualized as a universal feature of socio-cultural systems ${ }^{5}$.

Object membership in either of the above categories means its existence within in a region of fixed assumptions and assessments where action is determined by a worldview. However, these two regions are separated by a third that Thompson referred to as a "flexibility region" with a vice versa situation where worldview is determined by action ${ }^{6}$. Access to this region of innovation and creativity is not freely available to all members of our society and is imposed through the existing social order. The operation of its control mechanism results in a situation when "the qualities objects have are conferred upon them by society itself and that and that nature (as opposed to our idea of nature) plays only the supporting and negative role of rejecting those qualities that happen to be physically impossible"7. To put it differently, those people near the top have the power to make things durable and to make things transient. Naturally, they can ensure that their own objects are always in the first category and that those of others are in the second.

${ }^{1}$ Marchand S. The Rhetoric of artefacts and the Decline of Classical Humanism: The Case of Josef Strzygowski // History and Theory. 1994. Vol. 33. № 4. P. 106-130.

${ }^{2}$ Miller P. N. History and Its Objects: Antiquarianism and Material Culture since 1500. Ithaca; London, 2017.

${ }^{3}$ Thompson M. Rubbish Theory: The Creation and Destruction of Value. London, 1979.

${ }^{4}$ Thompson M. Rubbish Theory... P. 7.

${ }^{5}$ Thompson M. Rubbish Theory... P. 88.

${ }^{6}$ Thompson M. Rubbish Theory... P. 88.

${ }^{7}$ Thompson M. Rubbish Theory... P. 9. 
The changes that prevent this system from stagnation are related to the possibility of transfer between the two categories. Such transition can be possible through the existence of a third category that is covert in contrast to the first two categories and is, therefore, not subject to the operation of the control mechanisms of our society: rubbish. A transient object declines in value, yet its material tissue (life span) remains. It is transferred into some sort of a timeless and valueless limbo. If it does not disintegrate, it can be rediscovered and transferred to durability ${ }^{8}$.

Pushing the boundaries between these categories and transfers is neither natural nor arbitrary, as it is the outcome of social forces mediated by knowledge, and as such may be seen as the bending of reality to fit the dominant theory ${ }^{9}$. Transfers between categories, acceptable yet tightly controlled, allow social mobility that is necessary for the development of society and prevent it from disintegrating in total egalitarian anarchy or caste-based stratification ${ }^{10}$. As Thompson notes, rubbish theory is applicable to ideas and individuals apart from objects. Objects may be assigned active roles similarly to persons. "In one situation it may be reasonable to assume that people are being manipulated by objects, in another we can assume that objects are being manipulated by people, and in a third that people are both manipulating objects and being manipulated by them" ${ }^{11}$. Thus, the idea of the active role played by objects in social life gradually took shape in humanitarian knowledge and eventually was established as the concept of agency as one of their key capacities.

Igor Kopytoff's "The cultural biography of things: commoditization as process," published in 1986, constitutes the next step in the analysis of this problem and attempts to study the role and place of things in the culture-forming act of continuous conflict between singularization and commoditization. Kopytoff makes the following observation: "Culture serves the mind by imposing a collectively shared cognitive order upon the world which, objectively, is totally heterogeneous and presents an endless array of singular things" ${ }^{12}$. Yet, approaching closely either polar extreme - (utter commoditization allowing exchanging anything for anything, or absolute singularization denying the existence of any equivalents - means that culture's basic functions are undermined and that society cannot exist in this context. While commoditization increases the homogeneity of values, culture's function consists in singularization: "Culture ensures that some things remain unambiguously singular, it resists the commoditization of others; and it sometimes resingularizes what has been commoditized"13. To this effect it is worth noting that power often asserts itself symbolically precisely by insisting on its right to singularize objects.

Singularity is peculiar to complex societies, where publicly recognized commoditization operates "side by side with innumerable schemes of valuation and devised by individuals, social categories, and groups, and these schemes stand in unresolvable conflict with public commoditization as well as with one another" ${ }^{14}$. Specific examples of this process may include

${ }^{8}$ Thompson M. Rubbish Theory... P. 10.

${ }^{9}$ Thompson M. Rubbish Theory... P. 102.

${ }^{10}$ Thompson M. Rubbish Theory... P. 110.

${ }^{11}$ Thompson M. Rubbish Theory... P. 136.

${ }^{12}$ Konыmоффф И. Культурная биография вещей: товаризация как процесс // Социология вещей. М., 2006. С. 141.

${ }^{13}$ Копытофф И. Культурная биография вещей... С. 145.

${ }^{14}$ Копьттофф И. Культурная биография вещей... С. 153. 
private collections and defining boundaries of heritage manifested, for example, in cultural heritage struggles between monument protection activists and public authorities. Control over the latter implies control over social self-presentation and cannot be excluded from the intricate system of relations of domination and subordination.

The principles underlying biographies of things in simple and complex societies are generally similar to those underlying biographies of persons in these societies. In the former case, social identities of both persons and things are relatively stable, and changes in them are normally conditioned more by cultural rules Any thing that does not fit the categories is clearly anomalous and is to be singularized or cast out. In the latter case, both have multiple conflicting social identities, which inevitably leads to uncertainty in their evaluation and identity, and "an eventful biography of a thing becomes the story of the various singularizations of it, of classifications and reclassifications in an uncertain world of categories whose importance shifts with every minor change in context" 15 . Therefore, according to Kopytoff, things can be fully understood solely if processes and cycles of their production, exchange, and consumption are looked at as a whole rather than singularly, because objects change through their existence, which is almost inevitably related to accumulating new histories ${ }^{16}$.

Kopytoff's key conclusion, that society constructs both persons and objects concurrently and in the same way, was translated in a series of semantic studies of the category of things to which the problem of context change is most relevant, i.e. museum collection items.

Canadian semiotics specialist $\mathrm{E}$. Taborsky was among the first students of this problem in the 1980-1990s. In her view, the interpretation of objects as signs, i.e. as socially meaningful objects, is one of key museum function. This puts on the agenda three categories of problems that can be regarded as core areas of these studies: the nature of the society, the nature of objects, and the way objects generate meaning and interpretation. All the three categories are closely interrelated.

This is associated with the common philosophy of signs followed by Taborsky and by the conviction that objects on their own are meaningless. They exist only as signs. Meaning is rather acquired than inherited. The meaning of an object arises only within the context of discursive interaction of the observer with the object. However, interpretation is a social process that is based on presuppositions specific to a given category of persons constituting the same community. Independent and cognitively neutral observers do not exist. In this aspect, Taborsky follows H.-G. Gadamer's hermeneutical approach of preunderstanding. For this reason, the initial social interpretation of an object may be different from its museum interpretation. Sign-based interaction can be understood as interaction between three conceptual realities: material, group, and individual ${ }^{17}$. Material reality is made up of both actual objects and actions, and is never perceived in a direct sense, but only in a social, interpreted sense, as a system of signs that develop meaning. Group reality is synonymous to social consensus or common understanding of the meaning of existence as understood by the group and is what eventually makes a group into a society. It consists of an infrastructure that provides a frame in which discourse and interaction can take place, which in turn provides the

${ }^{15}$ Копытофф И. Культурная биография вещей... Р. 164-165.

${ }^{16}$ Gosden C., Marshall Y. The Cultural Biography of Objects // World Archeology. 1999. Vol. 31, No. 2. P. 170.

${ }_{17}$ Taborsky E. The discursive object // Objects of knowledge. Ed. by S. Pearce. London; Atlantic Highlands, 1990. P. 54. 
group members with a particular way of viewing the world. Group reality is totally created, has stability, and appears to be close to what C.S. Peirce defined as "thirdness." Individual reality is related to personal interpretation of the sign that an individual produces when he uses that sign. However, it cannot be entirely unique due to the social nature of interpretation referred to above ${ }^{18}$. Taborsky offers the following definition: "A sign... can have a number of interpretations...An individual can 'interpret' yet cannot entirely change the basic consensus of a sign's meaning." The sign is the bridge between material and individual reality, for "we do not understand the object directly in its own physical essence but only within a group or social reality"19.

Recognizing the existence of two basic paradigms in understanding the interaction between these two realities (observation and discourse), Taborsky denies that the former arises from Cartesian philosophy (claiming it is as obsolete) and adheres to the latter. According to her: "In discourse both you and the object are interactive sharing the same space and time". Interpretations generated in the course of such interaction are always context-related and interactive. These two paradigms lead to the introduction of certain museological approaches. The observation paradigm is based on a static object with an inherent meaning (equivalent to the aggregate of measurable objective data). The curator gathers and exhibits all the data related to the item, and the visitor perceives everything exactly the way it is exhibited. The discursive model implies that the object and the observer exist only within the same discursive format, rather than beyond $\mathrm{it}^{20}$. Objectively, this concept lacks space for a channel of communication between the object and the observer, because it is in the course of interaction that they come into existence. In other words, a specific artefact made for a specific ritual exists solely during this ritual, and its pre-ritual existence is similar to what M. M. Bakhtin defined as "text in potential".

In her article published in 1988, Taborsky identifies four verbs that define the actions relevant to successful operation of social systems: name, store, teach, and use. They form the basis for a coherent pattern of understanding within a group and make the group a society. ${ }^{21}$ According to Taborsky, "a namer can be considered a social agent, who has the social right to give a unit, be it material or mental, a "name." In this regard, the museology context requires the existence of three "namers": the namer of the object in the original society; the museum curator defining the object in the museum; and the museum visitor. Their definitions of the same object may differ ${ }^{22}$. The same artefact may virtually constitute three different objects.

Taborsky proposes using the sign classification introduced by C. S. Peirce for the interpretation of the discursive object. Peirce categorized signs into "qualisigns," "sinsigns," and "legisigns". According to Taborsky, museums traditionally operate only at the first level of object significance, i.e. the "qualisign" level. Qualisigns mean an experience or sensation with no reference. This could be, for example, the experience of a heritage house. A sinsign is

${ }^{18}$ Taborsky E. The discursive object... P. 55-58.

${ }^{19}$ Taborsky E. The discursive object.... P. 58.

${ }^{20}$ Taborsky E. The discursive object... P. 63.

${ }^{21}$ Taborsky E. The semiotic structure of societies: the four verbs of cognition // Methodology and Science. 1988. Vol. 21. Is. 3. P. 202-214.

${ }_{22}$ Taborsky E. The discursive object. P. 66. 
an understanding of the singular identity and the causes of those sensations. Finally, a legisign is the understanding of the object within a social group in a particular time and space ${ }^{23}$.

A similar approach, also focused on semiotic studies and object interpretation, was developed in numerous works of the British museologist S. Pearce. In her approach to objects as being both metaphoric and metonymic, Pearce singles out three special characteristics: their social life; their power of physical survival that gives them a unique relationship to past events ('the real thing'); and their particular susceptibility to possession and evaluation ${ }^{24}$. In her opinion, it is the ability of objects to be simultaneously signs and symbols, to carry a true part of the past to the present, but also to bear perpetual symbolic interpretation ${ }^{25}$. As signifiers and signified, museum objects carry emotional resonance and intellectual interest ${ }^{26}$. Australian museum studies specialist L. Smith has reflected on the problem of the emotional component of man-object interaction in work on emotional connotations of "heritage experiences." The impact of sensory registers of any culture on the perception of an object by its members, and related social practices, have become a special focus of a dedicated collaborative study, whose authors have demonstrated that our understanding of material culture is determined by the priority of a vision specific to Western culture. Clearly, this attitude is questionable and requires further contextualization - as J. Crary notes, until the late 18th century even in European culture "haptic and optic are not autonomous terms but together constitute an indivisible mode of knowledge" 27 .

An attempt to trace the evolution of the relationship between the world of things and the sensory profile of man was made by British archaeologist and anthropologist C. Gosden, who offered a new approach to the concept of the "biography of things" originating in Kopytoff's ideas. According to Gosden, "people and objects gather time, movement and change, they are constantly transformed, and these transformations of person and object are tied up with each other" 28 . Gosden distinguishes two categories of things, depending on their capability to accumulate histories: objects that can accumulate biographies to themselves, and objects that contribute to ceremonial or performance biographies. The former category of objects accumulate their own inherent meaning and therefore are viewed as social actors. The latter accrue meaning only in the context of some performance (ritual, ceremony, etc.) and lack any inherent meaning when taken out of that performative context $\mathrm{t}^{29}$.

Referring to a specific historical case of changes in Britain's material culture during the Roman conquest, Gosden tries to answer the question "What Do Objects Want?" He offers an object-focused approach to the analysis of agency to demonstrate how artefacts act en masse to shape people and their social relations, thus defining the lifeworld. For a better understanding of this phenomenon, he explores four key issues that include form (morphology and decoration), genealogy (object history), source (object geography), and effect (sensory and emotional responses) ${ }^{30}$. According to Gosden, forms of objects have effects on people, but

${ }^{23}$ Taborsky E. The discursive object. P. 71-72.

${ }^{24}$ Pearce S. Museums, Objects and Collections. Washington, D.C., 1993. P. 17.

${ }^{25}$ Pearce S. Museums, Objects and Collections. P. 27.

${ }^{26}$ Pearce S. Museums, Objects and Collections. P. 38.

${ }^{27}$ Крэри Д. Техники наблюдателя. М., 2014. С. 87.

${ }^{28}$ Gosden C., Marshall Y. The Cultural Biography of Objects. P. 169.

${ }^{29}$ Gosden C., Marshall Y. The Cultural Biography of Objects. P. 176-177.

${ }^{30}$ Gosden C. What Do Objects Want? // Journal of Archaeological Method and Theory. 2005. Vol. 12. Is. 3. P. 198. 
only when modulated through histories of descent and modification and notions of source or provenance $^{31}$. Further elaboration of this approach to interpreting "the thing in history" came from philosophical schools that emerged at the turn of the $20^{\text {th }}$ century, e.g., new materialism, actor-network theory, and assemblage theory, that promoted the denial of the Cartesian subject-object dichotomy and a new approach to the role of "non-humans" (a term introduced by B. Latour) in forming and developing social relations.

\section{Photographs as obJects}

Museum theory has recently incorporated the conceptualization of museum objects in terms of their materiality and mobility, a tendency exemplified by the introduction of the terms "biography," "itinerary," and "network" into museum research. When it comes to photographs as objects, in particular as museum objects, things become even more complex. It took photography researchers a long time to realize that photographs are not only two-dimensional images, but also three-dimensional things. Although photographs are simultaneously images and physical objects, in a visual act the prevailing tendency is to privilege their status as images over that as objects ${ }^{32}$. As Patrick Maynard has argued, what has prevented us from understanding photographs as objects is the assumption that photography is essentially a depictive device and that its other uses are marginal ${ }^{33}$.

For Geoffrey Batchen, the prevalence of photography's depictive character is attributed to its supposed "transparency". Indeed, photography's conceptualization as a "transparent" medium with no innate characteristics is based for most theorists on its indexicality, i.e. its nature as a trace of the real world that imprints itself on the photographic surface. Undoubtedly, the perception of the photograph as a trace of reality privileges the image content over every other feature. In effect, as Batchen points out, "in order to see what the photograph is 'of' we must first suppress our consciousness of what the photograph 'is' in material terms" ${ }^{34}$.

Nevertheless, despite the photograph's tendency to become detached from its materiality and function, it does exist materially in the world as chemical deposits on paper, as an image mounted on a multitude of cards of different sizes, shapes and, colors, as subject to various presentational forms such as frames and albums ${ }^{35}$. It has volume, opacity, tactility, and a physical presence, and hence participates in social and cultural experiences, provoking embodied and sensuous interactions ${ }^{36}$. As it exists in space and in time, a photograph moves into different locations, following lines of passage and usage that project it through the world ${ }^{37}$. In short, thinking materially about photography acknowledges photography as a physical object in all its materiality, and encompasses processes of making, distributing, consuming, using, discarding, recycling, and so on ${ }^{38}$.

${ }^{31}$ Gosden C. What Do Objects Want? P. 199.

${ }^{32}$ Edwards E., Hart J. Introduction: Photographs as objects // Photographs, objects, histories: on the materiality of images. London; New York, 2004. P. 2.

${ }^{33}$ Maynard P. The Engine of Visualisation. Ithaca; New York, 1997. P. 24.

${ }^{34}$ Batchen G. Photography's Objects. Albuquerque, 1997. P. 2.

${ }^{35}$ Edwards E., Hart J. Introduction: Photographs as objects. P. 1.

${ }^{36}$ Batchen G. Photography's Objects. P. 2.

${ }^{37}$ Straw W. The thingness of things, Keynote address for interrogating Subcultures conference, University of Rochester, March 27, 1998, Invisible Culture. Access Mode http://www.rochester. edu/in visible culture/issue2/straw.htm\#BackFromNote1 (last visited - 22 September 2018).

${ }^{38}$ Attfield J. Wild Things: The material culture of everyday life. Oxford, 2000. P. 3. 
Photography's belated entry into the Museum has been perplexed by a long debate over its artistic merit that has long tortured the medium's history. In its first years, photography seemed to be closer to science than art. Many of the earliest photographers considered themselves scientists, engineers, and inventors. Bound by its indexical nature, photography had a long way to go to make its way into the art museum ${ }^{39}$. To be established as art, photography had to appropriate the status of a painting. Rejecting qualities inherent to the photographing medium, Pictorialist photographers applied soft focus and new forms of toning to create blurry and painterly effects. By the early $20^{\text {th }}$ century, however, photographers began to accept the medium's inherent precision, and modernist "straight" photography started to gain ground ${ }^{40}$.

The famous New York Museum of Modern Art (MoMA), considered by several scholars to be the ideological home of modernism, was the first art museum to initiate a photography department in 1940, although photography's status as an art form was still not secure. Photography's assimilation into the modernist museum was effectuated in the 1960s, when MoMA curator John Szarkowski (1925-2007) praised photography as a fragment of actuality that is pictorially organized to reflect a strong personal vision. In his view, "straight" photography distances itself from works of imagination (painting), and is elevated to a genre that is legitimate to its medium, democratic in its subject matter, and having a strong formal component ${ }^{41}$.

Photography's claim to artistic validity acquired a broader scope in the late 1970s, when $19^{\text {th }}$ century photographs taken for documentary reasons at the time of their creation were reevaluated on the basis of "artists" who made them. Their reclassification was done according to their newly acquired value defined by their newly established status as art. Douglas Crimp mentions the case study of the New York Public Library, whose Art, Prints, and Photographs Division was inaugurated with the 1981 exhibition "96 Images: From Talbot to Stieglitz"42. Organized by Julia van Haaften, the exhibition presented photographic masterpieces that had been brought to light thanks to the curator's efforts to identify, relocate, and hence preserve many of original photographs hidden in different departments of the Library. Being reclassified, these photographic prints, almost valueless until recently, acquired a new life-span as, to quote Crimp, urban poverty becomes Jacob Riis and Lewis Hine, while the portraits of Delacroix and Manet become portraits by Nadar and Carjat. Crimp related several changes that occurred in this author-based redistribution of knowledge: what was once housed in the Jewish Division under the classification "Jerusalem" was then found in Art, Prints, and Photographs under the classification "Auguste Salzmann"; What was Egypt become Beato, or du Camp, or Frith; and the expression of emotions forgets Darwin to become Guillaume Duchene de Boulogne; and the list goes on ${ }^{43}$. According to Crimp, if photography was invented in 1839 , it was only discovered in the 1960 s and 1970 s — that is, photography as an essence,

${ }_{39}$ Wells L. Photography as Art // Photography: A Critical Introduction. Ed. by L. Wells. London; New York, 2015. P. 291-292.

${ }^{40}$ Rosenblum N. A World History of Photography. New York, 1997. P. 297-304.

${ }^{41}$ Szarkowski J. The Photographer's Eye. New York, 1980.

${ }^{42}$ Haaften van J. From Talbot to Stieglitz: Masterpieces of Early Photography from the New York Public Library. London, 1982.

${ }^{43}$ Crimp D. The Museum's Old, the Library's New Subject // On The Museum's Ruins. Ed. by D. Crimp. Cambridge, Massachusetts; London, England, 1993. P. 74. 
photography itself ${ }^{44}$. Crimp was among other photography scholars who critiqued the loss of understanding being effected by the transfer of photographs from the drawers of the archive to the walls of the art museum.

Thomson's rubbish theory finds in the New York Public Library a re-categorization an interesting application: these original photographs, which used to exist in a timeless and valueless limbo, had the chance of being discovered at this later date by a creative curator and were successfully transferred to durability ${ }^{45}$. That is, a transient print integrated within a book collection was transformed into a durable artwork. What happens, though, when the photographic object does not fall into either of these categories, but rather belongs to what Thomson calls the covert category of rubbish ${ }^{46}$ For, if the value of the prints hidden in New York Public Library's various departments skyrocketed, they still possessed a certain value. What if there were objects of zero value, almost rejected by an institution?

\section{OBJECTS OF ZERO VALUE? \\ THE MULTIPLE “LIVES" OF THE KREMLIN's DESTRUCTION PHOTOGRAPHS}

Two years ago the Byzantine Library in Paris undertook the project of its relocation. Within this context, the then-Director of the Library initiated the project of "cleaning up" the library. The institution's history goes back to 1929, when the well-known Byzantine scholar Thomas Whittemore (1871-1950) founded a small library annexed to the Byzantine Institute, which was to be called the Paris Library of the Byzantine Institute ${ }^{47}$. Born in 1871 in Massachusetts, Whittemore was a multi-specialist: English professor, amateur archaeologist, humanitarian, and passionate advocate of cultural and art preservation, who was known for leading the preservation of Byzantine mosaics and wall paintings in Hagia Sophia and Kariye Camii in Istanbul, Turkey, between the 1930s and 1940s ${ }^{48}$. Based initially in Boston, MA, the Byzantine Institute, also known as the Byzantine Institute of America, was established by Whittemore to summarize his research endeavors. Its mission was "to conserve, restore, study, and document the Byzantine monuments, sites, architecture, and arts in the former Byzantine Empire"49. In the following decades, the Institute assumed several fieldwork activities, including the uncovering and restoring of original mosaics in Hagia Sophia, Istanbul, which lasted until the early 1960s. After this, due to insufficient funding, it officially ended its administrative and fieldwork operations and transferred its assets to Dumbarton Oaks ${ }^{50}$.

${ }^{44}$ Crimp D. The Museum's Old, the Library's New Subject. P. 74.

${ }^{45}$ Thomson M. Rubbish Theory: The Creation and Destruction of Value.

${ }^{46}$ Thomson M. Rubbish Theory... P. 9.

${ }_{47}$ "Historique du fonds (Historical Note)", Salamandre. Fonds Whittemore - Institut byzantin. Historique du fonds. Octobre 2017. Access mode: https://salamandre.college-de-france.fr/ functions/ead/attached/FR075CDF BYZ-WHI/FR075CDF BYZ-WHI e0000054.pdf (last visited - 17 September 2018).

${ }^{48}$ Razon $R$. Thomas Whittemore's manifold narrative // Colligere, 16/05/2017. Access mode: https://archibibscdf.hypotheses.org/486 (last visited - 17 September 2018)

${ }_{49}$ The Byzantine Institute and Dumbarton Oaks Fieldwork Records and Papers, ca. late 1920s 2000s, MS.BZ.004-Historical Note, Image Collections and Fieldwork Archives, Dumbarton Oaks, Trustees for Harvard University, Washington, D.C. Access mode: https://www.doaks.org/resources/ bliss-tyler-correspondence/annotations/byzantine-institute (last visited - 17 September 2018).

${ }^{50}$ Byzantine Institute. Ibid. 
The Paris Library's initially limited book holdings, based on Whittemore's personal collection, were to serve the research needs of French and American Byzantine scholars, as well as specialists from such other countries as England, Greece, Russia, Bulgaria, and Belgium. Among the services offered in the Library were support for publications by scholars affiliated with the Byzantine Institute, such as interpretations and translations of inscriptions, and primary and secondary sources in Russian, Greek, and French. According to Boris N. Ermoloff, Librarian and Administrator of the Paris Library from ca. 1929 to 1967, the Paris Library aspired to evolve into an "international scientific centre" for Byzantine studies, a place where "Franco-American cultural relations" were cultivated, constituting "an element of American influence in Europe in general" 51 . Apart from its book collection, the Library included a few Coptic textiles, possibly obtained or purchased during Whittemore's trips to Egypt, as well as Russian and Greek icons possibly given to or purchased by Whittemore during his trips to Eastern Europe ${ }^{52}$. Gradually, the Library collected, acquired, and received primary and secondary sources, such as rare books and manuscripts, offprints, newspaper clippings, periodicals, as well as a significant collection of photographic documentation of Byzantine art and architecture. The Library changed status in the 1950s when management was transferred from The Byzantine Institute to the École nationale des Langues orientales vivantes $(\mathrm{ENLOV})^{53}$. Officially now known as the Bibliothèque byzantine (Fonds Thomas Whittemore - Institut byzantin), the Library changed locations several times in the decades that followed. After its recent relocation, the Library is currently housed at the Marcelin-Berthelot campus of the Collège de France ${ }^{54}$.

In the process of the Library's last (2016) relocation, a clearance project was initiated that led to the disposal of material. The procedure for discarding archival material was based on the fact that the documents ceased to have the validity and relevance they once had for the institution. Several discards were scavenged by Georges Kiourtzian, a scholar who is specialized in Byzantine epigraphology and is associated with the Bibliothèque byzantine. He donated them to the Museum of Byzantine Culture of Thessaloniki, Greece, confirming his long relation with the Greek institution ${ }^{55}$.

Among these are a collection of seventeen mounted silver-prints that date to the period following the October Revolution of 1917 and portray destruction to churches and the other Kremlin monuments in Moscow due to bombardments. More specifically, of the Kremlin

${ }^{51}$ See: Subgroup 01, Series 01, "Memorandum / Of the Librarian of the Paris Library of the Byzantine / Institute, Inc., June 15, 1950". Quoted in Razon R. Thomas Whittemore's manifold narrative; "Memorandum / Of the Librarian of The Paris Library of the Byzantine / Institute, Inc., June 15, 1950." Fonds Thomas Whittemore - Institut byzantin, Subgroup 01-Series 01, Bibliothèque byzantine, Collège de France. Quoted in Razon $R$. Thomas Whittemore's manifold narrative. ${ }_{52}$ Major B. "The Socialite Archaeologist". Thomas Whittemore (1871-1950) and the roles of patronage, politics, and personal connections in cultural heritage preservation, BA hons thesis, 2010. Rutgers University. Access mode: https://history.rutgers.edu/docman-docs/undergraduate/ honors-papers-2010/209-the-socialite-archaeologist/file (last visited - 14 September 2018).

${ }^{53}$ Now known as the Institut national des langues et civilisations orientales (INALCO).

${ }^{54}$ Historique du fonds (Historical Note). Salamandre. Fonds Whittemore — Institut byzantin. Historique du fonds. Ibid.

${ }_{55}$ We would like to thank Georges Kiourtzian for the information he provided on the provenance of the photographs he donated. 
monuments represented in the photographs of the Kiourtzian donation, seven document the Assumption Cathedral (Uspensky Sobor), with photographs taken after the bombardment portraying both the building's exterior and interior. The photographs also feature the Chudov Monastery, the Church of the Twelve Apostles, the Tower of Ivan the Great, and the Gates

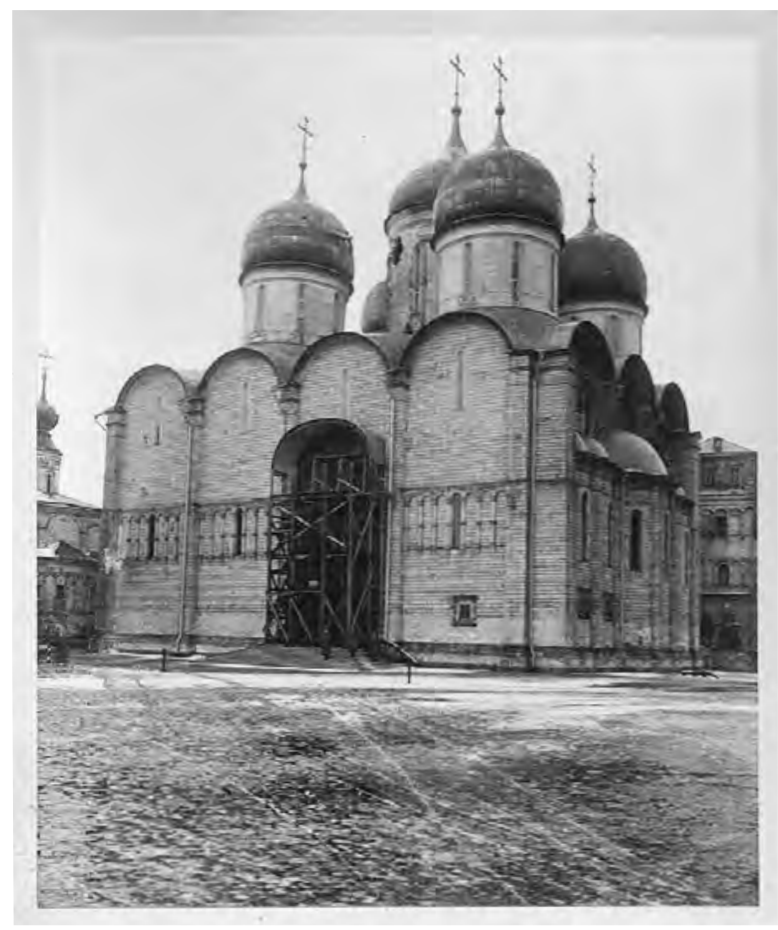

Picture 1. Uspensky Sobor, Kremlin Moscow, after bombardment 1918,

silver print mounted on cardboard

(C) Museum of Byzantine Culture, Georges Kiourtzian donation Troitsa and that of Saint Nicholas. Of particular interest are photographs that document the interiors of the Patriarchal Museum in the Kremlin. The original photographs are mounted on cardboard bearing handwritten inscriptions on the reverse side. These are in English and briefly describe the monuments in each picture, most stating the period in which they were taken, i.e. "just after bombardment" and "after bombardment 1918."

Although the director and curators of the Museum of Byzantine Culture accepted the collection, integrating them within the broader collections of the Museum seemed to have divided the institution's staff. On one hand, there was a certain enthusiasm stemming from the rarity of the material and the mystery that had to be solved regarding the photographs' conditions of creation and use. On the other, there was a kind of skepticism that mostly concerned the photographs' apparent irrelevance to the Museum's main research focus. However, incorporating the photographs into the Museum's collection required their documentation. In this framework, research into the provenance of the material had to be undertaken to answer to questions that had arisen mostly in regards to the type of material and ways in which it was related to Whittemore's activity.

A more careful look revealed a polygonal stamp on most of the prints, which with the help of Russian colleagues ${ }^{56}$ was identified as the stamp of Pyotr Petrovich Pavlov (1860-1925?), a Moscow-based photographer ${ }^{57}$. Pavlov and his studio affiliates had been working on

${ }^{56}$ Пармузина И. С. Фотографии последствий обстрела Московского Кремля в конце октября - начале ноября 1917 г. в собрании Музеев. Московского Кремля // Сборник докладов конференции “Фотография в музее” 16-18 мая 2017 г. СПб., 2017. С. 10-15.

${ }_{57}$ Шипова T. Н. Фотографы Москвы (1839-1930): Биографический словарь-справочник. М., 2006. - At this point we would like to thank Nadezda Drozdova-Pichurina for her guidance in Russian literature on historical photography. 
documentation of the Kremlin since 1910, within the framework of commissions related to the restoration of the Assumption Cathedral (Uspensky Sobor) ${ }^{58}$.

As the minutes of the Holy Council of the Russian Orthodox Church reveal, not long after the Kremlin shelling, a Special Commission was established within the Holy Council, presided over by Metropolitan Benjamin of St. Petersburg, to evaluate damage caused to the monuments ${ }^{59}$. Among its decisions were the photographic recording of the destruction. According to sources of the era, two days after the bombardment was over, Sunday November 5, 1917,

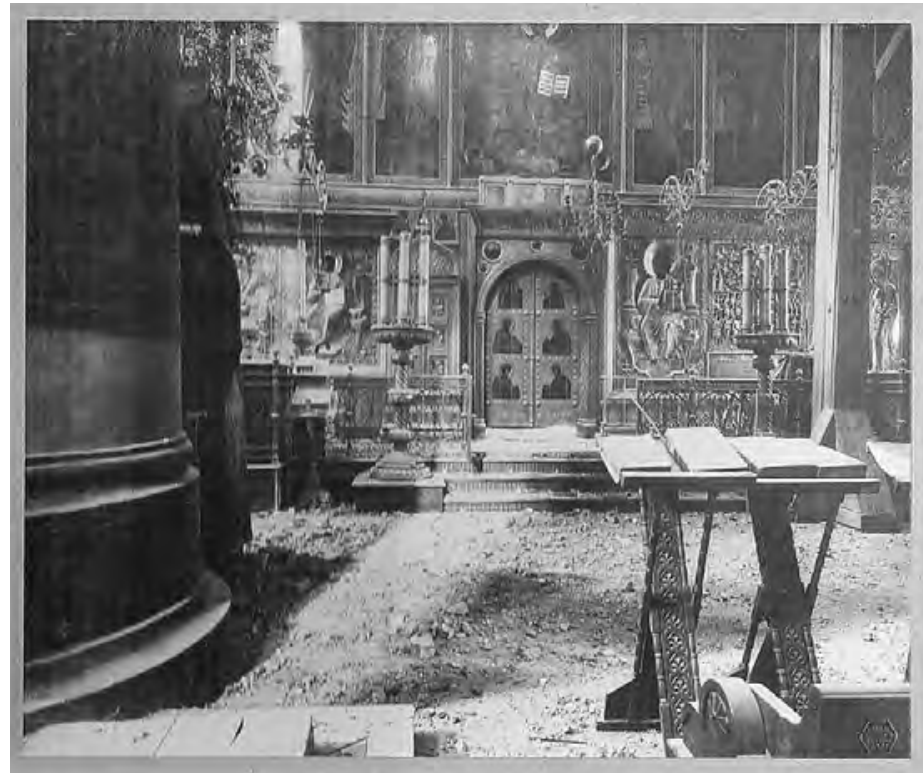

Picture 2. Uspensky Sobor, Kremlin Moscow, just after bombardment (interior view), silver print mounted on cardboard

(C) Museum of Byzantine Culture, Georges Kiourtzian donation the Holy Council reached the decision to "invite the photographer P. P. Pavlov to take pictures of all damage in the cathedrals of the Assumption, Saint Nicholas, as well as in the Tower of Ivan the Great" ${ }^{60}$. Hence, it should be assumed that it was Pavlov's experience with the specific monuments that turned out to be decisive in his undertaking the photographic documentation of damage in the Kremlin.

The photographs from the Kiourtzian donation must have been part of this photographic commission, as a quick comparison with photographs found in the photographic collections of the Moscow Kremlin Museums reveals ${ }^{61}$. However, despite the identification of the photographic studio, as well as of the commission in the framework of which the prints were produced, several questions still arise when one seeks to illuminate the entire "itinerary" these photographs followed to find their way to Thomas Whittemore's personal archive.

${ }^{58}$ Пармузина И. С. Фотографии последствий обстрела Московского Кремля в конце октября начале ноября 1917 г. в собрании Музеев. Московского Кремля. С. 10-15.

${ }_{59}^{59}$ Документы Священного Собора Православной Российской Церкви 1917-1918 годов. M., 2013. T. 2. Протоколы Соборного Совета. - We would like to thank Professor Tatiana Vitautasovna Chumakova for the bibliographical information provided to us.

60 "Пригласить фотографа П. П. Павлова сделать снимки всех повреждений в Успенском и Николо-Гостунском соборах и Ивановской колокольне" (ОРПГФ Музеев Московского Кремля. Ф. 5. Д. 12. Л. 38).

${ }^{61}$ Пармузина И. С. Фотографии последствий обстрела Московского Кремля в конце октября - начале ноября 1917 г. в собрании Музеев. Московского Кремля. С. 10-15. 


\section{The TALented Mr. WhitTemore: \\ Photography IN THE SERVICE OF ANTI-BOLSHEVIK PROPAGANDA}

The answer to how Pavlov's photographs ended in Whittemore's archive is found in the scholar's multi-faceted activity in Russia, which surpassed his archaeological and restoration research. Highly conscious of the humanitarian crisis caused by World War I, Whittemore devoted himself to relief work, serving first with the Army Medical Service in France, and later in Bulgaria. In November 1915, he arrived in Russia to join the Grand Duchess Tatiana Nikolaevna's Petrograd-based relief efforts. Upon his return to the U.S. he worked under the auspices of the Committee for the Relief of Refugees in Russia. A few other trips to Russia followed, while the country was in the turmoil first of the February and later of the October Revolutions ${ }^{62}$. Concentrating his attention on the needs and education of young Russian refugees affected by the October Revolution, Whittemore mobilized his fundraising skills, appealing to civic-minded patrons for donations. At the same time, a number of his publications appeared in the daily and periodical press, in which he shared his views of the rapidly changing social and political climates in Europe ${ }^{63}$.

In 1918, Whittemore expressed his anti-Bolshevik stance in an article he wrote for National Geographic under the title "The Rebirth of Religion in Russia: The Church Reorganized While Bolshevik Cannon Spread Destruction in the Nation's Holy of Holies"64. Part of the article is dedicated to destruction of Kremlin monuments caused by recent shelling while, in compliance with the magazine's strategy, an extensive illustration was employed to move the reader. Interestingly enough, the majority

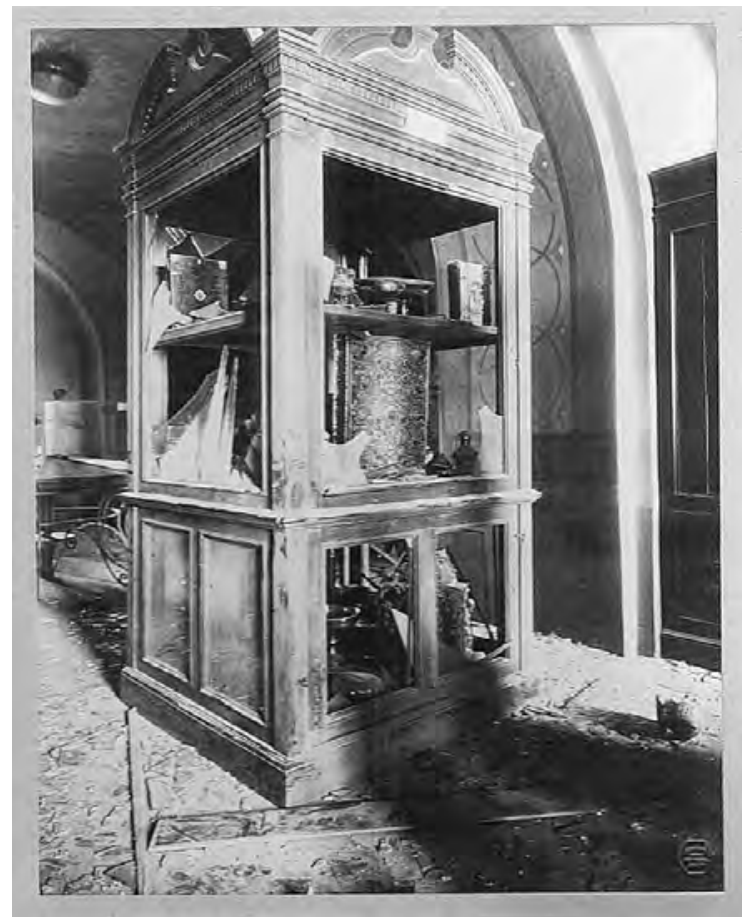

Picture 3. "Patriarchal Museum", silver print mounted on cardboard (C) Museum of Byzantine Culture, Georges Kiourtzian donation

${ }_{62}$ Who Was Thomas Whittemore? Dumbarton Oaks Research Library and Collection. Access Mode: https://www.doaks.org/resources/online-exhibits/before-byzantium/who-was-thomaswhittemore (last visited - 14 September 2018); Razon R., Thomas Whittemore's manifold narrative // Colligere, 16/05/2017. Access mode: https://archibibscdf.hypotheses.org/486 (last visited - 17 September 2018).

${ }^{63}$ Whittemore T., trans. The Russian // Atlantic Monthly 123, no. 1 (January 1919). P. 1-12; Mme. X. Talks of Russia // Chicago Daily Tribune, January 26, 1919.

${ }^{64}$ Whittemore T. The Rebirth of Religion in Russia: The Church Reorganized While Bolshevik Cannon Spread Destruction in the Nation's Holy of Holies // National Geographic. 24, (JulyDecember, 1918). P. 378-401. 
of photographs that illustrate the article are found in the small collection Georges Kiourtzian donated to the Museum.

The missing element that explains how these photographs, commissioned by the Special Commission of the Holy Council of the Russian Orthodox Church and taken by Pavlov's studio, ended in National Geographic is answered by Whittemore himself: in a short note, he expressed his gratitude to his friend Bishop Nestor, the distinguished missionary Bishop of Kamchatka, for graciously providing him with notes of his experience and photographic material taken in the Kremlin by permission of the Bolshevik government ${ }^{65}$. A member of this Special Commission to evaluate damage to the Moscow Kremlin, Bishop Nestor of Kamchatka was also the author of an illustrated brochure titled The Shooting of the Moscow Kremlin, which appeared in $1917^{66}$. The publication of the anti-regime polemical text resulted in Nestor's arrest by the Bolsheviks and his imprisonment for a month.

Nestor made a detailed description of the destructions to the Assumption Cathedral, Saint Nicholas, the Bell Tower of Ivan the Great, the Archangel Cathedral, the Twelve Apostles Cathedral, and all the other Kremlin monuments. He even estimated the cost of the damage, e.g. 25,000 rubles required for the glass windows of the Assumption Cathedral. Nevertheless, far from writing a typical report on the destruction of the Kremlin, Bishop Nestor surpassed his role as a member of the Special Commission by producing a deeply emotionally charged text. His descriptions of Moscow families in the street and children in despair are a clear appeal to the reader's sentiment.

His tone turned aggressive when he attributed the Kremlin damage to a deliberate act of vandalism by the Bolsheviks. For him, the Bolsheviks had not attacked the Kremlin to extinguish their enemies, as there were only a few cadets defending the place. Their real aim was to destroy the centuries-long Russian Orthodox culture through injury to sacred national monuments of the Kremlin's churches. Nestor's denouncement of this sacrilegious act was completed by his use of quotes taken from the Bible, as well as anecdotal stories such as that of the Chinese workman who accused the Russians of lack of kindness for their attack on their God ${ }^{67}$. Nestor's emotionally charged essay seems to have had a strong impact on Whittemore, as his article in the National Geographic proves. Apart from the illustrations, whose contribution Whittemore himself acknowledged, the National Geographic article seems to quote a good part of Nestor's text unaltered, repeating even anecdotal eyewitness accounts, such as the story of the Chinese workman or aphorisms such as "The history of Russia is the history of the monuments of Kremlin" 68 .

Whittemore's article further described the 1918 Easter Service that he witnessed, as his biography informs us $^{69}$. His tone was nostalgic for the revival of a triumphant religious past, and at the same time resentful for the sacrilegious Bolshevik regime. Whittemore's narration goes back to the events that followed the abolition of the Tsarist regime in early 1917 and the subsequent restoration of the Russian Patriarchate ${ }^{70}$. Anecdotal stories, such

${ }^{65}$ Whittemore T. The Rebirth of Religion in Russia. P. 379.

${ }^{66}$ Нестор Камчатский. Расстрел Московского Кремля (Access mode: https://www.pravmir.

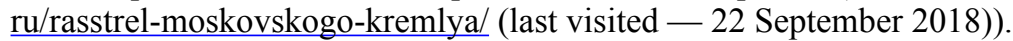

${ }^{67}$ Ibid.

${ }^{68}$ Whittemore T. The Rebirth of Religion in Russia. P. 379.

${ }^{69}$ Major B. "The Socialite Archaeologist". P. 23.

${ }^{70}$ Whittemore T. The Rebirth of Religion in Russia. P. 389. 
as that of the peasant who intensely asked to "have a father," were mobilized to support his view that the Russian Orthodox Church was restored, fulfilling the overriding urge of the Russian people. The election of Patriarch Tikhon was described in every detail, although Whittemore did not hesitate to refer to difficult conditions under which this procedure took place, that is during armed conflict in Moscow, when part of the city was cut off from the building in which the Council sat ${ }^{71}$. At this point, Whittemore profiled the new Patriarch, who he confessed was a former acquaintance. Well aware of the impact that the Patriarch's background would have on the magazine's American public, the author introduced the new head of the Russian Church as the one-time Bishop of the North American Diocese from 1898 to $1907^{72}$, And Tikhon's American background was apparently reassuring for readers of National Geographic. To Whittemore, his election represented the new birth of the free Russian Church, as well as the hope for a new republican Russia ${ }^{73}$. He concluded his article acknowledging that, at this moment of confusion in the country, the Church was the only institution that still stood on its feet, expressing at the same time the wish that the republican example of the Sobor would in due course pave the way for a similar triumphant reconstruction of Russian politics ${ }^{74}$.

Unquestionably, Whittemore's article was a polemical piece of political propaganda. His ideological stance is easily discerned in his lines: he dreamt of the end of political instability caused by the Bolshevik uprising, and the establishment of a liberal republican regime for Russia modeled after that in the United States. The photographs illustrating the article were mobilized to appeal to reader sentiment. Although he did not clearly repeat Nestor's accusations of deliberate vandalism, Whittemore severely denounced Kremlin attacks, with the photographs as evidence of Bolshevik barbarism: photographic records of collapsed walls, broken windows, looted altars, and destroyed furniture demonstrate the fury of the attacks. Indissolubly interwoven with the photographic medium's "realist" approach, as well as with photography's perception as incontrovertible evidence of a true event, the photographic documentation of destroyed historical buildings and artworks was used as war propaganda. Mobilizing photographs of a destroyed heritage for propaganda reasons was not a new practice: in the early years of photography, the Italian Stefano Lecchi photographed villas and palaces destroyed by French troops during the occupation of Rome. Recent research has interpreted those salt prints as anti-Napoleonic propaganda in a liberal Roman environment ${ }^{75}$.

In this same perspective, during World War I, almost at the same time as the October Revolution, new technical standards allowed quick and effective application at the front; photographic records of damaged historical buildings or artworks played a significant role in international propaganda campaigns. Photographs of damage in the Kremlin could be compared with the shelling of the cathedral of Reims by German troops in September 1914. According to French commentators, the shelling of the Cathedral revealed the real character not only of Germany's military leaders and their commander in chief, Kaiser Wilhelm II, but also of the German people in general, accused of a deliberate act of vandalism. For them, the Germans had gone to war not only for political reasons, but also to destroy French culture,

${ }_{11}$ Whittemore T. The Rebirth of Religion in Russia. P. 390.

${ }^{72}$ Whittemore T. The Rebirth of Religion in Russia. P. 396.

${ }^{73}$ Whittemore T. The Rebirth of Religion in Russia. P. 392.

${ }^{74}$ Whittemore T. The Rebirth of Religion in Russia. P. 401.

${ }^{75}$ Critelli M-P. Stefano Lecchi. Un fotografo e la repubblica romana del 1849. Rome, 2001. 
specifically the cathedral as a sacred national monument. This was part of an aggressive tone in French propaganda, in which the Germans were denounced as Barbarians, Vandals, and Huns. In German counter-propaganda, commentators from Belgium, France, and other countries were denounced as intentionally falsifying reports about the events. The German press went on to discuss military reports of the Reims Cathedral shelling, according to which the French concentrated troops in front of the Cathedral and used its towers as observation points to monitor Germany troop movements. Far from being dismissed as a typical wartime dispute, the Reims Cathedral incident became a typical example of how photography employed as political propaganda may lead to an acrimonious controversy ${ }^{76}$.

\section{CONCLUSION: ON THE MATERIALITY OF PHOTOGRAPHS}

For art historian John A. Walker, "meaning is crucially influenced by the moment of production, but it is also subject to changes as the photograph enters into relationship with new circumstances and publics". Walker emphasized the need to examine the life of an image as well as its birth, as well to consider its circulation and currency as it moves through time and space from context to context and is used by various individuals and groups for different purposes, until eventually it is destroyed or lies forgotten in an archive ${ }^{77}$. In other words, Walker warned us against interpreting photography that is solely based on the image content; instead, he set the issue of a photograph's mobility, circulation, and reinterpretation within an entirely new context.

The Kremlin photographs from the Kiourtzian donation provide an exceptional case of this methodological shift towards the acknowledgement of photography's materiality. It is illustrative of research tendencies formed under the influence of the so-called "material turn" in the social sciences, which in the last decades has increasingly stressed the centrality and complexity of social meaning in relation to objects and sociability of objects. Accordingly, an object cannot be entirely apprehended at any single point in its existence, but should be interpreted as part of an enduring process of production, exchange, usage, and meaning. Objects are thus actively involved in social relations, not being merely passive entities in these processes $^{78}$.

Within the context of this article, we have sought to explore the trajectory of this particular group of photographs, so as to reveal the histories hidden behind their dramatic changes of ownership: from the photographic studio of P. Pavlov, to the Special Commission on damage in the Kremlin, to Bishop Nestor of Kamchatka, to Thomas Whittemore and his publication in National Geographic, to the Paris Bibliothèque byzantine and their discarding during the Library's clearance project, to their preservation by Georges Kiourtzian and their new "life" in the collection of the Museum of Byzantine Culture. In their itinerary, the photographs have been subject to several changes of physical locations (Russia-France-Greece), of materials (mounted on cardboard, reproduced in National Geographic), and of use (records for assessing

${ }^{76}$ Dilly H. Septembre 1914 // Revue germanique international. 2000. № 13. P. 223-237; Goldhahn A. Traces of Devastation: Photography, Cultural Heritage, and Propaganda during World War II // Representations of the Nazi Occupation: Photography, history, memory. Ed. by I. Katsaridou, I. Motsianos. Thessaloniki, 2016. P. 102-118.

${ }_{77}$ Walker J. A. Context as a Determinant of Photographic Meaning // The Camerawork Essays. Context and meaning in photography. Ed. by J. Evans. London, 1997. P. 52-63.

${ }^{78}$ Edwards E., Hart J. Introduction: Photographs as objects. P. 4. 
damage for the Russian Church Special Commission, propaganda material for Bishop Nestor and Thomas Whittemore, archival documents for the Parisian Bibliothèque byzantine, and finally objects for the Museum of Byzantine Culture). All this long itinerary of the Kiourtzian photographs testifies to the way in which complex patterns of value and relationships ascribed to photographs are momentarily fixed, only to change again.

The Kremlin photographs have accumulated biographies as they have repeatedly moved between people, places and uses. In their new repository at the Museum of Byzantine Culture, the curators are not in a position to agree on the reason that made them accept this donation as relevant to their field of acquisitions. Was it the history of the Kremlin monuments, as representatives of a widespread post-Byzantine heritage? Was it the personal story of Thomas Whittemore, distinguished Byzantine scholar, founder of the prestigious Dumbarton Oaks and famous restorer of the Hagia Sophia mosaics? Or was it an excellent case of photography's use as political propaganda?

Whichever the case may be, the legitimate approach (in museum terms) implies the photographs' evaluation in their entirety. Their integration within the collection of the Museum should acknowledge all the social biographies, that is their physical modifications, their movement through space and time, or their institutional frameworks that construct their own "economies of truth" ". It is only through an open-ended approach that the Museum will be able to take advantage of the multiple layers of memory that the photographs' multiple biographies have accumulated.

\section{Информация о статье}

Авторы: Ананьев, Виталий Геннадьевич - кандидат исторических наук, старший преподаватель, Санкт-Петербургский государственный университет, Россия, v.ananev@spbu.ru; OrcID http://orcid. org/0000-0001-7413-6339;

Кацаридо, Иро - PhD in Art History, куратор современного и актуального искусства, Музей византийской культуры, Салоники, Греция, irokatsaridou@hotmail.com

Заголовок: This obscure object of desire: object, photography, museum and damaged churches [Этот смутный объект желания: предмет, фотография, музей и разрушенные церкви]

Резюме: В центре внимания статьи коллекция фотографий, относительно недавно (в 2016 г.) переданная в дар Музею византийской культуры (Салоники, Греция) Йоргисом Киурцаном, византинистом, связанным с парижским College de France. 17 фотографий, датированных периодом Октябрьской революции 1917 года, изображают разрушения, нанесенные в ходе бомбардировок церквям и другим памятникам московского Кремля. Некогда бывшие частью архива Томаса Уитмора, американского византиниста, эти фотографии были отвергнуты Византийской библиотекой в Париже, попали в коллекцию Йоргиса Киурцана и в итоге оказались в собрании Музея византийской культуры. В статье рассматривается непростая биография этих фотографий: от создания как документов к использованию в качестве инструмента пропаганды через изъятие за ненужностью из собрания Византийской библиотеки к новой жизни в качестве артефактов в Музее византийской культуры. В статье анализируются неоднозначные нарративы фотографий, а плюсы и минусы, предполагаемые их включением в музейную коллекцию, представлены через анализ конфликтной динамики развития самой коллекции. Конкретный пример анализируется в контексте общих подходов, предложенных современной гуманитарной мыслью для концептуализации предмета как элемента исторического исследования.

Ключевые слова: вещь, предмет, музейный объект, фотография, теория хлама, биография объекта.

Литература, использованная в статье:

Attfield, Judith. Wild Things: The material culture of everyday life. Oxford: Berg, 2000. 315 p.

Batchen, Geoffrey. Photography's Objects. Albuquerque: University of New Mexico Art Museum, 1997. 15 p. Crimp, Douglas. The Museum's Old, the Library's New Subject // On The Museum's Ruins. Ed. by Douglas Crimp. Cambridge, Massachusetts; London, England: The MIT Press, 1993. P. 66-83.

${ }^{79}$ Edwards E., Hart J. Introduction: Photographs as objects. P. 5. 
Critelli, Maria Pia. Stefano Lecchi. Un fotografo e la repubblica romana del 1849. Rome: Retablo, 2001. $168 \mathrm{p}$.

Dilly, Heinrich. Septembre 1914 // Revue germanique internationale. 2000. № 13. P. 223-237.

Edwards, Elizabeth; Hart, Janice. Introduction: Photographs as objects // Photographs, objects, histories: on the materiality of images. London; New York: Routledge, 2004. P. 1-15.

Goldhahn, Almut. Traces of Devastation: Photography, Cultural Heritage, and Propaganda during World War II // Representations of the Nazi Occupation: Photography, history, memory. Ed. by I. Katsaridou; I. Motsianos. Thessaloniki: Museum of Byzantine Culture, 2016. P. 102-118.

Gosden, Chris. What Do Objects Want? // Journal of Archaeological Method and Theory. 2005. Vol. 12. Is. 3. P. 193-211.

Gosden, Chris; Marshall, Yvonne. The Cultural Biography of Objects // World Archeology. 1999. Vol. 31. No. 2. P. 169-178.

Haaften, van Julia. From Talbot to Stieglitz: Masterpieces of Early Photography from the New York Public Library. London: Thames and Hudson, 1982. 128 p.

Major, Ben. "The Socialite Archaeologist". Thomas Whittemore (1871-1950) and the roles of patronage, politics, and personal connections in cultural heritage preservation. BA hons thesis, 2010. Rutgers University. (Access mode: https://history.rutgers.edu/docman-docs/undergraduate/honors-papers-2010/209-the-socialitearchaeologist/file (last visited - 14 September 2018)).

Marchand, Suzanne. The Rhetoric of artefacts and the Decline of Classical Humanism: The Case of Josef Strzygowski // History and Theory. 1994. Vol. 33. № 4. P. 106-130.

Maynard, Patrick. The Engine of Visualisation. Ithaca; New York: Cornell University Press, 1997. 337 p.

Miller, Peter N. History and Its Objects: Antiquarianism and Material Culture since 1500. Ithaca; London: Cornell University Press, 2017. 312 p.

Pearce, Susan M. Museums, Objects and Collections. Washington, D.C.: Smithsonian Institution Press, 1993. $296 \mathrm{p}$.

Razon, Rona. Thomas Whittemore's manifold narrative // Colligere, 16/05/2017 (Access mode: https:// archibibscdf.hypotheses.org/486 (last visited - 17 September 2018))

Rosenblum, Naomi. A World History of Photography. New York: Abbeville Press, 1997. 695 p.

Straw, Will. The thingness of things: Keynote address for interrogating Subcultures conference, University of Rochester, March 27, 1998, Invisible Culture. (Access mode http://www.rochester.edu/in visible culture/ issue2/straw.htm\#BackFromNote1 (last visited - 22 September 2018)).

Szarkowski, John. The Photographer's Eye. New York: The Museum of Modern Art, 1980. 155 p.

Taborsky, Edwina. The discursive object // Objects of knowledge. Ed. by S. Pearce. London; Atlantic Highlands: Athlone Press, 1990. P. 50-77.

Taborsky, Edwina. The semiotic structure of societies: the four verbs of cognition // Methodology and Science. 1988. Vol. 21. Is. 3. P. 202-214.

Thomson, Michael. Rubbish Theory. The creation and destruction of value. Oxford: Oxford University Press, 1979. $228 \mathrm{p}$.

Walker, John A. Context as a Determinant of Photographic Meaning // The Camerawork Essays. Context and meaning in photography. Ed. by J. Evans. London: Rivers Oram Press, 1997. P. 52-63.

Wells, Liz. Photography as Art // Photography: A Critical Introduction. Ed. by L. Wells. London; New York: Routledge, 2015. P. 289-353.

Konытофф $\phi$, Игорь. Культурная биография вещей: товаризация как процесс // Социология вещей. Москва: Территория будущего, 2006. С. 134-168.

Крэри, Джонатан. Техники наблюдателя. Москва: V-A-C Press, 2014. 250 c.

Пармузина, Ирина Сергеевна. Фотографии последствий обстрела Московского Кремля в конце октября - начале ноября 1917 г. в собрании Музеев Московского Кремля // «Фотография в музее»: Сборник докладов конференции, 16-18 мая 2017 г. Санкт-Петербург: РОСФОТО, 2017. С. 10-15.

Information about the article

Authors: Ananiev, Vitaly — PhD in History, Assistant Professor, Institute of Philosophy, St. Petersburg State University, St. Petersburg, Russia, v.ananev@spbu.ru; OrcID http://orcid.org/0000-0001-7413-6339;

Katsaridou, Iro - PhD in Art History, Curator of Modern and Contemporary Art, Museum of Byzantine Culture, Thessaloniki, Greece, irokatsaridou@hotmail.com.

Title: This obscure object of desire: object, photography, museum and damaged churches 
Abstract: The paper focuses on a collection of photographs recently (2016) donated to the Museum of Byzantine Culture of Thessaloniki, Greece, by Georges Kiourtzian, a Byzantine scholar associated with the College de France in Paris. The 17 mounted silver-prints date from the October Revolution of 1917 and portray the destruction by bombardments of churches and other monuments in the Kremlin, Moscow. Once part of the archive of Thomas Whittemore, the American Byzantine scholar, the photographs were discarded by the Byzantine Library in Paris, only to be collected by Georges Kiourtzian and then to find their way to the collection of the Museum of Byzantine Culture.

This paper sheds light on the complicated itinerary of those photographs: from their production as documentation, to their use as propaganda material, to the Byzantine Library and their eventual discarding, and finally to their new life as museum artefacts in the Museum of Byzantine Culture. The disputed narratives of the photographs are revealed, along with challenges and potentials that reorganization and integration in this recent museum presents for unravelling contested dynamics of the collection.

Keywords: thing, object, photography, rubbish theory, biography of object.

\section{References:}

Attfield, Judith. Wild Things: The material culture of everyday life. Oxford: Berg Publ., 2000. 315 p.

Batchen, Geoffrey. Photography's Objects. Albuquerque: University of New Mexico Art Museum Press, 1997. $15 \mathrm{p}$.

Crary, Jonatan. Tehniki nablyudatelya [Techniques of the Observer]. Moscow: V-A-C Press, 2014. 250 p. (in Russian).

Crimp, Douglas. The Museum's Old, the Library's New Subject, in On The Museum's Ruins Ed. by D. Crimp. Cambridge, Massachusetts; London, England: The MIT Press, 1993. Pp. 66-83.

Critelli, Maria Pia. Stefano Lecchi. Un fotografo e la repubblica romana del 1849. Rome: Retablo Publ., 2001. 168 p. (in Italian).

Dilly, Heinrich. Septembre 1914, in Revue germanique internationale. 2000. № 13. Pp. 223-237.

Edwards, Elizabeth; Hart, Janice. Introduction: Photographs as objects, in Photographs, objects, histories: on the materiality of images. London; New York: Routledge, 2004. Pp. 1-15.

Goldhahn, Almut. Traces of Devastation: Photography, Cultural Heritage, and Propaganda during World War II, in Representations of the Nazi Occupation: Photography, history, memory. Ed. by I. Katsaridou, I. Motsianos. Thessaloniki: Museum of Byzantine Culture Press, 2016. Pp. 102-118.

Gosden, Chris. What Do Objects Want?, in Journal of Archaeological Method and Theory. 2005. Vol. 12. Is. 3. Pp. 193-211.

Gosden, Chris; Marshall, Yvonne. The Cultural Biography of Objects, in World Archeology. 1999. Vol. 31. No. 2. Pp. 169-178.

Haaften, van Julia. From Talbot to Stieglitz: Masterpieces of Early Photography from the New York Public Library. London: Thames and Hudson Publ., 1982. 128 p.

Kopytoff, Igor'. Kulturnaya biografija veschey: tovarizacija kak process [The cultural biography of things: Commoditization as process], in Sociologija veschey [Sociology of things]. Moscow: Territoriya buduschego Publ., 2006. P. 134-168. (in Russian).

Major, Ben. "The Socialite Archaeologist”. Thomas Whittemore (1871-1950) and the roles of patronage, politics, and personal connections in cultural heritage preservation. BA hons thesis, 2010. Rutgers University. (Access mode: https://history.rutgers.edu/docman-docs/undergraduate/honors-papers-2010/209-the-socialitearchaeologist/file (last visited - 14 September 2018)).

Marchand, Suzanne. The Rhetoric of artefacts and the Decline of Classical Humanism: The Case of Josef Strzygowski, in History and Theory. 1994. Vol. 33. № 4. Pp. 106-130.

Maynard, Patrick. The Engine of Visualisation. Ithaca; New York: Cornell University Press, 1997. 337 p.

Miller, Peter N. History and Its Objects: Antiquarianism and Material Culture since 1500. Ithaca; London: Cornell University Press, 2017. 312 p.

Parmuzina, Irina Sergyeevna. Fotografii posledstvij obstrela Moskovskogo Kremlâv konce oktâbrâ načale noâbrâ $1917 \mathrm{~g}$. v sobranii Muzeev Moskovskogokremlâ [Photos of the consequences of the shelling of the Moscow Kremlin in late October - early November 1917 in the collection of the Moscow Kremlin Museums], in "Fotografiâ v muzee". Sbornik dokladov konferencii 16-18 maâ 2017 g. ["Photography in the Museum”. Collection of reports of the conference, May 16-18, 2017]. Saint-Petersburg: ROSFOTO Press, 2017. Pp. 10-15. (in Russian).

Pearce, Susan M. Museums, Objects and Collections. Washington, D.C.: Smithsonian Institution Press, 1993. $296 \mathrm{p}$. 
Razon, Rona. Thomas Whittemore's manifold narrative, in Colligere. 16/05/2017. (Access mode: https:// archibibscdf.hypotheses.org/486 (last visited - 17 September 2018)).

Rosenblum, Naomi. A World History of Photography. New York: Abbeville Press, 1997. 695 p.

Straw, Will. The thingness of things: Keynote address for interrogating Subcultures conference, University of Rochester, March 27, 1998, Invisible Culture. (Access Mode http://www.rochester.edu/in visible culture/ issue2/straw.htm\#BackFromNote1 (last visited - 22 September 2018)).

Szarkowski, John. The Photographer's Eye. New York: The Museum of Modern Art Publ., 1980. 155 p.

Taborsky, Edwina. The discursive object, in Objects of knowledge. Ed. by S. Pearce. London; Atlantic Highlands: Athlone Press, 1990. Pp. 50-77.

Taborsky, Edwina. The semiotic structure of societies: the four verbs of cognition, in Methodology and Science. 1988. Vol. 21. Is. 3. Pp. 202-214.

Thomson, Michael. Rubbish Theory. The creation and destruction of value. Oxford: Oxford University Press, 1979. $228 \mathrm{p}$.

Walker, John. A. Context as a Determinant of Photographic Meaning, in The Camerawork Essays. Context and meaning in photography. Ed. by J. Evans. London: Rivers Oram Press, 1997. Pp. 52-63.

Wells, Liz. Photography as Art, in Photography: A Critical Introduction. Ed. by L. Wells. London; New York: Routledge Publ., 2015. Pp. 289-353. 